\title{
Preparing for disaster: a comparative analysis of education for critical infrastructure collapse
}

\begin{abstract}
This article explores policy approaches to educating populations for potential critical infrastructure collapse in five different countries: the UK, the US, Germany, Japan and New Zealand. 'Critical infrastructure' is not always easy to define, and indeed is defined slightly differently across countries - it includes entities vital to life, such as utilities (water, energy), transportation systems and communications, and may also include social and cultural infrastructure. The article is a mapping exercise of different approaches to critical infrastructure protection and preparedness education by the five countries. The exercise facilitates a comparison of the countries and enables us to identify distinctive characteristics of each country's approach. We argue that contrary to what most scholars of security have argued, these national approaches diverge greatly, suggesting that they are shaped more by internal politics and culture than by global approaches.
\end{abstract}

Key words: preparedness; preparedness education; critical infrastructure; critical infrastructure collapse; disaster; comparative

\section{Introduction}

This article explores how populations are educated for potential critical infrastructure collapse in five different countries: the UK, the US, Germany, Japan and New Zealand and considers whether their approaches converge rather than diverge, as some scholars of security studies would argue. In particular, it is considered that terrorism (and particularly 9/11) produced a set of conditions that pulled diverging national systems towards each other. For example, Liotta (2002) argues that states are becoming increasingly similar in treating national and human security as a conjoint issue. Similarly, Lutterback (2005) considers that European states are synchronising in the ways in which they have militarised their security apparatus. This is not necessarily the case in terms of all aspects of securitisation, though, and we focus on one security area - 'critical infrastructure protection (CIP)'. Although 'critical infrastructure (CI)' is not always easy to define, and indeed is defined slightly differently across countries, it includes entities vital to life, such as utilities (water, energy), transportation systems and communications, and may also include social and cultural infrastructure. There are both real and perceived threats to the infrastructure such as terrorism, natural disasters, cyber attacks and even riots and industrial disputes. The purpose of this article is to describe national approaches to CIP and preparedness education for potential CI collapse in the five countries. This is a mapping exercise which facilitates a comparison of the five countries and enables us to identify distinctive characteristics of each country's approach. The focus of the paper is state policy, rather than practice. Moreover, whilst the private sector has been engaged to varying degrees in CIP and preparedness in the five countries, this paper focuses on state approaches.

Besides 'CIP', we also consider government approaches to 'emergency management' or 'disaster management', which often overlap with CIP. 'Preparedness' among the population is also a linked concept, defined as: 'The capacities and knowledge developed by governments, professional response organisations, communities and individuals to anticipate and respond effectively to the impact of likely, imminent or current hazard events or conditions (UN 2008).' Thus, methods of enhancing preparedness include research, resourcing, education and training. Our focus in this paper is 'preparedness education'. 
Protection of the critical infrastructure is an area which has undergone extensive securitisation, particularly since the attacks on the US on 9/11. By securitisation, we mean the way in which certain aspects of life which may not have traditionally been seen as security issues, are considered as such. Most scholars of securitisation would argue that national approaches to securitisation are converging (see Liotta 2002; Lutterbeck 2005) since the end of the Cold War, due to the effects of globalisation and new threats including the 'War on Terror' and climate change. They also assume that this convergence tends to be dominated by the approach of the US, as the most influential nation politically, culturally and economically. Our in-depth consideration of the approaches of five different developed countries allows us to suggest that in fact, when it comes to CIP and preparedness education, approaches tend to diverge rather converge, and the US is less dominant than commonly assumed. For example, although some literature has suggested that the private sector is very important in CIP protection and recovery (Cavelty and Kristensen 2008), and even that corporations use disasters to increase profits (Klein 2014) this would seem to be mainly indicative of the US model and not necessarily applicable to other national systems where the state has a greater role.

\section{Researching the complexity of CIP and preparedness education}

This article has been developed on the basis of the findings from the ongoing research project, Critical Infrastructure Failure and Mass Population Response. Cavelty and Kristensen (2008) consider that CI refers to those functions where 'their prolonged unavailability would, in all likelihood, result in social instability and major crisis'. It is made up of 'interconnected, complex and increasingly virtual systems. The most frequently listed examples of CIs encompass banking and finance, government services, telecommunications and information and communication technologies, emergency and rescue services, energy and electricity, health services, transportation, logistics and distribution and water supply'. The CI has also been referred to as 'lifelines'. The aim of the research is threefold. The first is to understand the complexity of the contexts within which systems and policies for CIP have been developed. CIP is a complex agenda because it requires inter-disciplinary thinking (as it involves both human and technical factors), it is subject to definitional problems, interconnections and interdependencies (some of which transcend national boundaries), and it involves complex legal, governance and ownership issues (it tends to include public, private and third sector organisations). We have undertaken a historical analysis of changes and continuities of CI systems and policies in the five countries. Secondly, the project aims to identify gaps between governments' perceptions of how the populations would respond in case of a national crisis. Although the population are not considered to comprise part of the CI (Preston 2009), their interactions and reactions to that infrastructure are very important in policy decision-making. For example, a major attack on transport infrastructure will present major challenges for the communications network and will elicit a variety of public responses (Preston et al 2011). Thirdly, the project aims to understand population response which informs emergency planning.

Methodologically, the research focused on national systems in developed countries. The countries were chosen on the basis of different 'welfare regimes' being broadly liberal market economies (the UK, the US and New Zealand) and broadly centralised market economies (Germany and Japan). The purpose is to compare the government approaches to CIP and consider if there are any common characteristics between the individual national systems. In terms of data collection, documentary analysis and archival research were undertaken to examine policy and legislation in the areas of CIP, risk and disaster management and 
preparedness education of the five countries. In order to obtain up-to-date information and expert perspectives, interviews were undertaken in all five countries using existing network of governmental and academic contacts and also developing new networks. The collected data were analysed manually to respond to the purposes of the research.

As indicated by Morris et al (2014), the framework of convergence and divergence has been widely applied in the field of comparative education. The former identifies commonalities across policies or systems and highlights convergence towards a 'global' model; whereas the latter focuses on variation across policies or systems and highlights the influence of local contexts. Whilst it is beyond the scope of this article to analyse precisely how and where the five national approaches converge and diverge, we draw on this framework to suggest that contrary to expectations, here is more divergence than convergence in the approaches, both to CIP and preparedness education.

It should be also noted that we are in line with the 'contrast of contexts' (Skocpol and Somers, 1980) approach as this macro-comparative mapping aims to identify the key characteristics of the approaches to CIP and preparedness through the analysis of countryspecific contexts. However, we do not intend to develop causal explanations in relation to CIP strategies and preparedness education to produce generalised knowledge. We hope to develop 'good portrayals of specific policy developments with their country-specific rationale and much of their rich complexity' (Skocpol, 1984: 371). The contrast provided by the comparison highlights variations in approaches to CIP and preparedness education across countries.

The following section presents the summaries of the five country cases. The summaries have been developed as follows: first, we probed the following questions for each country case for the purpose of the comparison, and then summarised each case highlighting distinctive characteristics.

\section{Approaches to critical infrastructure protection and preparedness education}

\section{The United Kingdom: Critical is secret}

The approach to CIP in the UK is one of secrecy, both in terms of how protection is organised, and how education for CIP failure is controlled. The history of CIP in the UK is one in which the security services have predominantly managed CIP co-ordination. This is despite the movement of ownership of the infrastructure from largely nationalised (in the 1970s) to largely privatised (from the 1980s onwards) organisations. Even before the cold war, infrastructure protection was part of the security services remit, but during this period (1960-1980) the UK government was highly concerned with a strategic focus on protecting the infrastructure. Strategic reserves, and sites for production, of food, oil and gas were protected and the owners of infrastructure sites would have even been provided with spaces in deep government shelters (Hennessy 2011). Infrastructure protection during this period, and up to 2007, was part of the domain of MI5 (Military Intelligence Section 5) with a department within MI5, the National Security Advice Centre (NSAC) that was responsible for providing advisory services to the UK government.

In 2007, NSAC was merged with another government department responsible for infrastructure protection to create a successor organisation, the CPNI (Centre for the Protection of the National Infrastructure). The remit of the CPNI is infrastructure protection 
in the major utilities sectors and it does not include population protection or responses to terrorism in public places (other than those which might impact on the critical infrastructure) which are the responsibilities of other government departments such as the Home Office based Office for Security and Counter-Terrorism. There is also inter-agency working within the security services on CIP with GCHQ (Government Communications Headquarters) supplying evidence and intelligence to CPNI and MI5 on infrastructure threats, particularly those of a cybersecurity nature. This means that the protection of the infrastructure is a shared secret amongst government security agencies, and the central core of the UK government.

Perhaps because CIP in the UK is such a domain of secrecy, it is necessarily delimited to a discrete number of sectors (there are nine current sectors, including things such as communications, energy and health) as to extend CIP across sites of public importance such as monuments, or events of state significance, would mean that there would be a veil of secrecy over the protection arrangements for the majority of public space in the UK. Anecdotally, such a secretive approach to CIP has positive and negative features for responding to emergencies involving the national infrastructure. For example, unlike the US, it is quite possible for emergency services to respond to an event on a possible CI site without knowing if this site was part of the CI, or knowing what exactly was being performed at that site. There are no maps of the UK CI in the public domain, and no information beyond a highly descriptive level concerning what is in the CI. Such things are classified as state secrets, accessible only to those with very high levels of security clearance. Therefore, the CI and CIP arrangements of the United Kingdom are not available for scrutiny. On the other hand, such an approach makes the exploitation of CIP plans by a malicious or terrorist group less likely.

Perhaps mirroring the secretive approach to CIP in the UK, the plans for population protection in the event of a critical CI failure are also secretive. Even as far back as WWI, the UK government has not particularly seen preparedness to be particularly important for the UK population as a whole (Preston and Kolkokitha 2012) and it is was only in the exceptional circumstances of WWII that the government reluctantly started to warn and inform the public concerning the obvious bombing threat to UK industry and residential properties. This exceptional period did not last far further than the early days of the Cold War (Grant 2010) when information campaigns and encouraging volunteering gradually disappeared and were virtually non-existent by the mid 1960s. Other than an embarrassing attempt by the government to encourage population preparedness with 'Protect and Survive' which, for various political and social reasons, was never repeated (Preston 2014) and a poorly received public information campaign in 2004 ('Preparing for Emergencies') there have been virtually no public efforts by UK governments to educate the public for CI failure. The experience of WWII has led to a national story, if not a myth, in the UK that the population is somehow resilient in the face of adversity and that we will 'Keep calm and carry on' in the event of a national crisis. Although this may be true of many populations in a disaster, there is no particular reason to assume that the UK would be exceptional in the event of a CI failure above a minimal size and duration.

In terms of the pedagogical approach to preparing people for CI failure we know that in areas that are close to areas which we can presume to be CI sites (Control of Major Accident Hazard Sites: COMAH Sites) the information provided to residents is didactic and gives basic information on what to do in a crisis. This involves, in the event of a warning signal, taking basic actions such as sheltering in place, shutting exterior doors and windows and listening information from local radio. This advice mirrors the current national policy of 'Go 
in, stay in, tune in' following from Preparing from Emergencies in 2004. The advice provided is didactic and individuated, as has been the general approach in the UK as a public information approach rather than a community, or lifelong learning, way of responding. Although the UK government has an extensive obligation to warn and inform in the event of a disaster (under the Civil Contingencies Act, 2007), there is no obligation for preparedness education (other than around COMAH sites).

In general, then, the UK has a very secretive approach to CIP and failure, and a corresponding didactic and subterranean approach to public education for CI failure. Although there is no super-ordinate agency for CIP and public response, the CPNI effectively takes one function (protection) without a public education function.

\section{The United States: Everything is critical}

The US also has an extensive security apparatus responsible for protection of the national infrastructure. A series of agencies from the cold war, including the Federal Civil Defense Administration (FCDA), Office of Defense Mobilisation (ODM), Federal Emergency Management Agency (FEMA) and the most recent Department of Homeland Security (DHS) have been established, primarily by executive order, to protect the infrastructure and organise an over programme of population preparedness. The CI is also under the remit of the Federal Bureau of Investigations (FBI) and the Secret Service who have a key role in government protection, including the protection of the President. The use of executive orders to establish these organisations who protect $\mathrm{CI}$ is not without controversy. Executive orders are signed by the president and do not require the usual democratic process of passing a bill through congress to be effective. These executive orders grant agencies such as the DHS sweeping powers in the protection of the CI which have raised concerns about civil liberties and human rights.

Within this extensive security apparatus, with super-ordinate agencies created by executive orders, the scope of CI is much more extensive than in any other of the countries discussed in this paper. The CI not only includes all of the utilities, industrial and communication sectors but also novel elements such as schools, national monuments and even presidential inaugurations. This power to make even the signing in of the President part of the CI gives the DHS a very powerful co-ordinating role in the nation's security. As various agencies and departments are involved in CIP this means that, although much of the CI is secret, other elements of CIP can be shared with contractors, private and public sector partners, and even the general public. As an example of this, the emerging national system for monitoring CI the Homeland Security Infrastructure System (HIFLD) contains both 'gold' layers (described as 'everything the government knows' about CI) and 'silver' layers (which can be shared). The HIFLD comprises a map of basically even CI asset and movement in the continental US which, as the CI is extensive, means virtually every 'thing' of value to the government. The HIFLD is not only wide, but 'deep' inasmuch as it comprises around $400-500$ layers of data that describe every asset. For a school, for example, some of these layers could potentially comprise the school's location geo-spatially, the layout of the school, and an evaluation of the ways in which resources are taken in and out of the building. Perhaps the one exception to the extensive role of government in infrastructure protection is that there is a clear expectation that, under Posse Comitatus Act the role of the US Army (other than the National Guard) to enforce US law is prohibited on US soil. However, although the Army is not (directly) involved in enforcing or providing CIP, the Army can support citizens in a crisis. Moreover, following recent legal challenges to Posse Comitatus the role of United 
States Northern Command (USNORTHCOM), a combat ready part of the US military with the purpose of defending the territory of the US on US soil) to restore order in a CI failure is a distinct possibility.

The inclusive approach to infrastructure protection taken by the DHS, and exemplified though HIFLD, means that various federal, state and local level agencies are all included in the national task of CIP. This requires 'acts of translation' in working out exactly what homeland security means in different contexts and, rather than being a monolithic, top-down enterprise (which is what might be expected from a super-ordinate agency such as the DHS) it has been described as being 'under construction' (Fosher 2009). In terms of academic support for CIP in the US, for example, although certain entities such as the DHS science centres are a critical part of the endeavour, this work is supported through a whole network of institutions which might be far removed from those created as part of the DHS monolith.

This open, and extensive approach, to CIP is reflected in extensive education for citizens concerning how to act in the event of a CNI failure or accident. This draws on a long history of civil defence education, with community as well as individual learning activities, across schools, higher education and adult education. Although not quite as extensive as in the 'Duck and Cover' days of the cold war, such disaster education initiatives are orientated around a 'bottom up' approach to infrastructure protection with citizens, and community groups taking a pro-active role. This long standing community and civic participation approach has been theorised in terms of social capital and even as 'smart swarms' where citizens act collectively to solve problems following a CI failure. However, there is still traction in civil society approaches to responding to disasters. Civic organisations, such as the Red Cross, the Citizen Corps and volunteer fire brigades are still mobilised in the event of a disaster and often work as first responders. However, the organic nature of US civil society means that the types of community learning and volunteering that occur after a CI failure have fundamentally changed. For example, after Hurricane Sandy in 2012, the Occupy organisation (more specifically 'Occupy Wall Street') were the first voluntary organisation to supply sustained and co-ordinated relief, particularly to the poorer areas of New York. In terms of timing and response, Occupy acted more quickly than either FEMA or the Red Cross. This shows the dynamic nature of civil society in the US, and for the need for existing community learning approaches in the US to act as a 'bridge' between traditional and non-traditional civic organisations.

\section{Germany: CIP as uncoordinated and preparedness as voluntary}

Unlike Japan and New Zealand, Germany is not prone to a large number of natural disasters, although it does suffer from severe weather events and flooding, and terrorism is regarded as a risk. It is however, relatively open about its approach to CIP. Germany defines the CI as 'Critical infrastructures are organizational and physical structures and facilities of such vital importance to a nation's society and economy that their failure or degradation would result in sustained supply shortages, significant disruption of public safety and security, or other dramatic consequences' (Federal Ministry of the Interior 2009, 4).

The following sectors are defined as the CI: transport, energy supply, IT and telecommunications, the finance and insurance industries, food and water supply, the authorities and legal services, miscellaneous (media, research centres, cultural assets and heritage). 
The notion of CIP has only really existed in this form since 2001/2002, in response to the attacks of 9/11 on the US, and the serious flooding along the River Elbe in summer 2002 which had disastrous consequences. Both events caused Germans to realise how unprepared they were for CI collapse. In response, Germany set up the new Federal Office for Civil Protection and Disaster Assistance in 2004. However, Germany still does not have a coordinated approach to CIP. Four different political offices include a CIP remit in their work: the Federal Office for Civil Protection and Disaster Assistance; the Federal Office for Information Security; the Federal Criminal Police Office; the Federal Technical Relief Agency.

There are no general laws which apply to the protection of critical infrastructure in Germany. The Civil Protection Law (1997, last amended 2009) pertains to the non-military measures which aim to protect the population, their homes and places of work, services important to life or defence, businesses or organisations and cultural heritage from the effects of war. Each of the German federal states have their own individual disaster management laws, unique to that state (Goersch and Werner 2011). There are also individual laws which apply separately to different aspects of the CI: e.g. Transport, the postal service, IT services (FOIS 2005). National emergency laws were passed in 1968 but have never been evoked (Hanshew 2012). As the CI is mostly in private hands, guidelines are published for businesses by the FOCPDA on CIP and interconnectedness, however, engagement with these is optional. There is no real public discussion around the concept of CI or CIP, and it could be argued that Germany's engagement with the notion is at least partly a reaction to the US' engagement with it (Kuhn 2005).

Although the notion of CIP is relatively new, West Germany does have an important tradition of civil defence. The focus of defence and security shifted from air defence, in the late 1940's, to civil population defence in 1954, and later just civil protection. The German Ministry of the Interior published a definition of the term civil defence in 1964: protection of state and government; civil protection; provision of supplies; support of the military (Franke 2008).

The focus throughout the Cold War in West Germany was defence against the Soviets, including East Germany, Germany itself being geographically located at the centre of this war.

However, the German government's approach to preparedness education has mostly been to downplay threats and not to involve the general population to a large extent. Post-war West Germany needed to emphasise the notion of security rather than risk and defence (Biess 2011; Hanshew 2012). West Germany was a new nation with a new, democratic government and a traumatised population. At the end of the war, unlike in the UK and the US, there was a widespread distrust of the state and a sense of 'injured citizenship', (Geyer 2001), thus the new West German government, directed of course by the Allies, needed to show it could offer security to the population (Hanshew 2012). The FOCPDA runs a programme of public awareness around preparedness, but, again, materials are only available if one contacts them directly. The only high profile public information campaign, 'Everybody has a chance' (1961) simply reactivated the suspicion of the German public that the government was trying to deceive them (Biess 2011). Germany does not have a national curriculum, and disaster preparedness tends not to be covered in formal schooling. Teaching materials produced by 
the FOCPDA are few, and are not distributed to schools, rather schools themselves contact the FOCPDA if they are interested.

The German government does however, promote and fund voluntary civil defence disaster relief services, in particular the Federal Technical Relief Service, which is an office of the Ministry of the Interior. This is a historic organisation, founded after WWII, but in fat a reawakening of a former civil defence organisation in existence since 1919. Volunteers are highly trained and specialised, and are active both nationally and internationally. However, research has shown that these are quite exclusive organisations, members tends to come from specific backgrounds and families who have traditionally been involved and be linked to local areas, and are mostly male (Wuerger 2009; Krueger 2007).

The general population in Germany remains comparatively under-educated and underprepared for disaster, with very low levels of awareness about the interconnectedness of the critical infrastructure and the implications of both past and future disasters for their lives.

\section{Criticality plus urgency in natural disaster prone Japan}

In Japan, 'social infrastructure' and 'social capital' are widely used to mean 'infrastructure'. The Ministry of Land, Infrastructure, Transport and Tourism is the ministry responsible for national infrastructure:

The MLIT is responsible for comprehensive and systematic use, development and protection of the land, through consistent maintenance of social infrastructure, development of transport policy, improvement of meteorological operation, as well as securing sea areas and ensuring public safety (MLIT 2015).

Although which infrastructure is 'critical' is not explicitly defined, the distinctive feature in the natural disaster prone country is that CIP has been undertaken hand in hand with natural disaster management. Japan is located in the Circum-Pacific Mobile Belt where seismic and volcanic activities are frequent. Although the country covers only $0.28 \%$ of the land area on the planet, $20.5 \%$ of the total number of Magnitude $6+$ earthquakes occurred in the world are in Japan, and $7.0 \%$ of the active volcanos in the world are situated in Japan. Japan has $0.3 \%$ of those who died because of natural disasters in the world, and $11.9 \%$ of the total damage costs of natural disasters in the world (Cabinet Office 2011). The country has also been subject to other types of natural disasters such as typhoons, torrential rains and heavy snow because of its geographical, topographical and meteorological conditions. Historically, therefore, a system of CIP has been largely driven by recurring natural disasters in Japan. One of the oldest records of disaster mitigation is on erosion control, which dates back to the seventh century (MLIT 2002). After WWII, control measures for natural disasters were prioritised in terms of infrastructure and population protection. In 1947, the Disaster Relief Act laid out the practicalities of post-disaster measures. This was followed by the Fire Control Act, the Flood Control Act, the Building Standard Act, and in 1961, overall control measures for natural disaster were summarised as the Basic Act on Disaster Control Measures. The act stipulated the setup of the Central Disaster Management Council of which role is to formulate and implement the Basic Disaster Management Plan. The council is currently situated within the Cabinet Office, and Earthquake Countermeasures Plans are also developed by the council (Cabinet Office 2014). There are more than 1,500 laws that refer to 'natural disasters' (Tsukui 2012), which indicate the criticality for Japan to put effective disaster measures in place. 
In recent years, criticality has risen because Japan entered into a 'quake-active' period (Cabinet Office 2002). The government set a goal to reduce damage by 50 percent in predicted large-scale earthquakes (Cabinet Office 2003), with an emphasis on preparedness education for in forthcoming disasters. This strategy derived from a lesson learned from the Hanshin/Awaji Earthquake (Hanshin earthquake) of 1995 that damage can be reduced, although disaster itself cannot be stopped. As well as criticality, urgency has been increasingly proclaimed particularly since the Great East Japan Earthquake of 2011. The incident was extraordinary for the following reasons. First, it was the largest recorded earthquake of Magnitude 9 in Japan, which affected a wide area (Japan Meteorological Agency 2014a). Second, the tsunami which followed the earthquake was also of the largest ever - 39.7m was recorded at the highest point (Japan Meteorological Agency 2014b) - and it was the tsunami more than the earthquake that led to 18,800 deaths and missing people (National Police Agency 2014). Third, the tsunami triggered the accident at the Fukushima Daiichi Nuclear Power Plant, which caused unmeasurable damage. The phrase 'beyond the scope of assumption [soteigai]' has been used to describe the scale of the mega earthquake and sweeping tsunami. The advancement of research and technologies has enabled detailed analyses of previous disasters and prediction of future ones. It is said that Tokai, Tonankai, Nankai and Metropolitan Epicentral earthquakes are likely to occur in the coming 30 years. The largest possible damage could be 18,000 fatalities, 360,000 totally collapsed housings and 370 billion pounds [57 trillion yen] in economic damage (Aota 2008). The 2011 experience has made the government and the people of Japan aware that a disaster 'beyond the scope of assumption' can happen, and that much more rigorous system for CIP and preparedness education are necessary.

Under such critical and urgent conditions, both the government and the people have valued disaster education [bosai kyoiku]. The approach has been legislated, overt and integrated into school curricula and lifelong learning programmes. The Basic Act on Disaster Control Measures obliges disaster prevention plans at the municipal and the prefectural levels and from certain businesses with public purposes (e-Gov 2013). In those plans, educational activities have to be defined and planned, responding to the needs of the region in which the organisation is situated. Both mass public education and provision of information, advice and guidance (IAG) have been the major pedagogic means for preparedness education. Mass public education is undertaken at school, in communities and industries. Preparedness activities such as evacuation drills are very much embedded in Japanese society.

Currently, school policy in relation to preparedness has been extended to Safety Education [anzen kyoiku] guided by the Ministry of Education, Culture, Sports, Science and Technology (MEXT). Safety Education is a multi-hazard approach which addresses traffic accidents, intruders and kidnapping, as well as natural disasters. The significance of teaching safety to pupils and managing safety of pupils have been increasingly emphasised, which resulted in the 2011 new Course of Study (national curriculum) in which 'enrichment of the education of safety' (MEXT 2015) was made compulsory for the first time. Moreover, after the 2011 Tohoku disaster, disaster education was revised by the expert committee coordinated by the MEXT. The committee confirmed that 20 percent out of 40 percent of the schools in the affected region which had not been engaged in regular discussion of disaster prevention had the highest fatalities amongst pupils. Those schools did not necessarily have a risk management manual in place and therefore, evacuation routes and areas were not learned by both pupils and staff members (MEXT 2012). The significance of preparedness education was evidenced by the disaster. On the basis of the committee's recommendations, 
the MEXT has produced a guideline to help schools develop their own preparedness education responding to their needs.

Outside of school curriculum, laws, policies, initiatives and learning resources concerning disaster management, as well as the information about real-time emergency situations have been made available in the public domain. Government ministries and agencies make a range of IAG, such as a portal site and leaflets, available on their homepages, which include the promotion of the notion of 'civil protection', following the enactment of a series of the Acts Concerning the Measures in Armed Attack Situations (Cabinet Secretariat 2013). These IAG tools are to advocate the population to prepare and protect themselves in case of a crisis, rather than waiting for the state's instruction and support.

Thus, in Japan, CIP has been discussed, to a large extent, in relation to natural disaster management. Due to the frequency and strength of the threat of natural disasters, the legislation and structure for disaster management has been well developed. Equally, education and lifelong learning for natural disasters has been usual, which is fully integrated into existing systems of education, civil activities and IAG. Since the 2011 experience, both the government and other stakeholders have been endeavoured to increase preparedness so as not to allow emergency situations 'beyond the scope of the assumption [soteigai]'.

\section{'Resilient New Zealand'}

Like Japan, New Zealand (NZ) is very prone to natural disasters, including potentially devastating earthquakes such as the one which struck in the Canterbury region in February 2011. NZ has long been aware of the need to take a structured and coordinated approach to protecting the national infrastructure and strengthening resilience at all levels (social, political, economic), and the approach taken is considered very innovative.

Until 1992, NZ had a traditional British Civil Defence model of national protection. From the mid 1990's however, in response to observations of a series of disasters internationally, NZ started moving from a reactionary approach and towards a proactive one. The Ministry of Civil Defence and Emergency Management (MCDEM) was created with the aim of grouping all threats together, and focussing on the response rather than the hazard.

The National CDEM Strategy 'establishes vision of a 'Resilient New Zealand' (MCDEM presentation 2013). MCDEM has a relatively high profile and has recently been moved to the Office of the Prime Minister to elevate its profile further and promote the resilience agenda. The Civil Defence Emergency Management Act (2002) created 'a structure to enable cooperative response and dispersed accountability' and 'an integrated, cooperative planning framework'. MCDEM focus on what they refer to as the 4 'R's': Reduction, Readiness, Response, Recovery. There are CDEM organisations at three levels: local, regional and national. Very innovatively, the 2002 act states communities should manage their own risks, which we discuss further below. MCDEM's role includes 'maintaining the CDEM framework policy development and advice; supporting capability building in the CDEM sector; public education and awareness; advice and advocacy for risk reduction; coordination across central government. They also administer the National Warning System; support coordination of regional events; and maintain capacity and capability to manage national events' (MCDEM presentation 2013). 
This civil defence strategy is complemented by a 'lifelines approach' to CIP. There has long been an appreciation of the importance of the protection and interconnectedness of the CI in NZ. In 1997 a national grouping was set up called NZ Lifelines, a coming together of the utilities. Each of the 16 regions of NZ has a Lifeline group. It is not legislatively driven, and participation is voluntary, as utilities are privately owned in NZ. Thus not all utilities are included e.g. fuel is not. The focus is on engaging, collaborating and networking to increase resilience. It is funded partially by the state (Earthquake Commission and MCDEM), and partially by dues paid by the utilities themselves to be part of the group.

The infrastructure resilience theme also runs through other areas of government. For example, the National Infrastructure Unit was created in the Treasury to enhance the structured approach, which adds value in terms of the integration with economy and growth and allows improved communication and capacity-building in resilience with businesses. However, at a local government level, the resilience message has had varied success. For example, Wellington Region Emergency Management Office regard the notion that communities should manage their own risks as an opportunity for creative resiliencebuilding. The team view the community as a resource rather than a hindrance and apply community development principles to the emergency management field. They focus on enhancing existing resilience, building social capital, empowering individuals and communities, capacity-building activities with the community. However, this approach was not taken in Canterbury, where at the time of the earthquake in 2011, there were tensions and clashes between communities and government responders. These tensions have continued into the current post-earthquake recovery phase, where there has been resistance in some communities and charities to the government's community resilience agenda, which is regarded by some as a way of justifying what is seen as their abdication of responsibility for some aspects of the recovery.

In many ways, NZ is aiming for a totally integrated approach in education for disasters as well. Disaster education is led by MCDEM. They lead on high profile public awareness campaigns, including national campaigns fronted by national celebrities and providing advice to the regions on regional campaigns to reinforce the preparedness message (Drop, Cover and Hold agenda). They also design materials for formal schooling at all levels. The Ministry of Education ensures that every pre-school receives a copy of the Turtle Safe DVD. The same character, Stan, is introduced in pre-school, and appears in all the materials, so that children identify with him as they grow up. The MCDEM also advises the Consortium of Crown Research Institutes on research themes.

Preparedness education is also carried out by other bodies. For example, the Earthquake Commission, a state-run insurance company which provides catastrophe insurance for geological disasters covering buildings, contents and land (unusually), also conducts research and educational activities with the levy. They see their role as 'developing sector capability' to bring together professionals and academics. They contribute to educational activities at the national museum, Te Papa, fund fieldtrips for schools and public awareness campaigns which aim at minimising damage for householders ('Fix, fasten, don't forget'); support university fellowships in both geological and social sciences; provide grants for postdocs; conduct collaborative projects with local authorities; and work collaboratively with the government to identify research themes.

NZ does have a National Curriculum, however, preparedness education does not feature on this, neither at primary nor secondary level. It is therefore only taught if teachers find it 
important. Recent research conducted at Victoria University shows that Christchurch teachers are not teaching about earthquakes at all at the moment, in order to help kids with the recovery and avoid traumatising them (Taylor and Moeed 2013). This evidence contrasts with MCDEM's claims that in places where there's been a recent disaster, there is a higher take-up of the educational materials. Equally, education research shows that the 'resilience agenda' is not replicated in formal education at all, which is of particular concern in education fields in a country where youth resilience is known to be comparatively low e.g. youth suicide rate very high.

In NZ then, infrastructure protection and resilience are high on the agenda politically and economically, but there are gaps in their approach, perhaps especially in formal education.

\section{Characterising the approaches to CIP and preparedness education}

The following table summarises our arguments of the five countries' characteristics of the approaches to CIP and preparedness education. We would argue that the comparison has revealed more variations than commonalities.

[Table 1 near here]

\section{Conclusion}

The above comparison suggests that there is a trend in all five countries to increase the emphasis on CIP. To a certain extent this does suggest a convergence in the securitisation of the politics of CIP as 'security' becomes relevant to a wide range of issues beyond the traditional view of military security (Buzan, Wæver and de Wilde 1998).

Beyond this umbrella policy discourse though, very little convergence can be identified. The governments of the US, Japan and NZ provide strong and explicit leadership in both CIP and preparedness education. Preparedness education is stipulated in the national curriculum in Japan, but not in the US and NZ. NZ emphasises (partially successful) 'community resilience'; whereas the US focuses on the securitisation of ever more aspects of life. CIP and preparedness feature less publicly in the UK and Germany. Both the UK and Germany take an exclusive approach to CIP and preparedness education but in a different way - the former focuses on physical sites which are considered critical, while the latter develops preparedness through involving a particular group of citizens in volunteering. Japan also promotes volunteering for disaster assistance, but its approach is more universal than Germany's. The only country which appears at first glance to be strongly influenced by the approach of the US is Germany, which had dismantled much of its civil defence infrastructure after the end of the Cold War, only to create a new agency, the FOCPDA in partial response to the attacks of 9/11. However, the similarities end there, with Germany's approach to CIP remaining fragmented, and the promotion of volunteering as a way of advancing preparedness among the population.

One might argue that there are obvious reasons why a country prioritises a certain agenda. For example, the US, Japan and NZ are prone to natural disasters, while the UK and Germany have experienced fewer of these, although both countries have faced serious flooding in recent years. The US, the UK, Germany and Japan all perceive themselves as particularly susceptible to terrorism. However, susceptibility to different threats only 
partially explains the divergence in approaches to CIP and population preparedness. Our study suggests much more that governments' approaches are only partly about actually rendering a country more secure for the general populations. In fact, it seems these agendas are influenced more by internal political agendas and economic approaches, and it is this which explains the divergence. 


\section{References}

Aota, R. et al. 2008. Urban Disaster Reduction in the Private Sector: Based on the Lessons from Past Disasters. Research Report of the Urban Safety Research Center, Kobe University 12: 177-183. http://www.lib.kobe-u.ac.jp/repository/81001286.pdf.

Balzacq, T., ed. 2011. Securitization Theory: How Security Problems Emerge and Dissolve. Abingdon: Routledge.

Biess, F. 2009. 'Everybody has a chance': Nuclear angst, civil defence, and the history of emotions in postwar West Germany. German History, 27 (2): 215-243. doi:10.1093/gerhis/ghp003.

Buzan, B., Wæver, O. and de Wilde, J. 1998. Security: A New Framework for Analysis. Boulder: Lynne Rienner.

Cabinet Office, Government of Japan. 2014. Important Councils, Cabinet Office. http://www.cao.go.jp/en/importantcouncil.html

Cabinet Office, Government of Japan. 2011. Disaster Management in Japan. Tokyo: Cabinet Office, Government of Japan. http://www.cao.go.jp/en/disaster.html.

Cabinet Office, Government of Japan. 2001. Chapter 1 The State of Natural Disasters and Countermeasures. White Paper on Disaster Management. Tokyo: Cabinet Office, Government of Japan. http://www.bousai.go.jp/kaigirep/hakusho/h13/bs2001/sb1.1.4.2.html.

Cabinet Secretariat, Government of Japan. 2014. The Structure for Security and Crisis Management in the Cabinet Secretariat. http://www.cas.go.jp/jp/gaiyou/jimu/fukutyoukanho.html\#sosiki.

Cavelty, M. and Kristensen, K.. 2008. Introduction: Securing the homeland: critical infrastructure, risk and (in)security. In Securing the Homeland: Critical Infrastructure, Risk and (In)security, ed. M. Cavelty and K. Kristensen, 1-14. London: Routledge.

Federal Office of Information Security (FOIS). 2005. Gutachten zur rechtlichen Analyse des Regelungsumfangs zur IT-Sicherheit in kritischen Infrastrukturen. Zusammenfassung. Bonn: FOIS.

Fosher, K. 2010. Under Construction: Making Homeland Security at the Local Level. Chicago: University of Chicago Press.

Franke, D. 2008. Ein Haus im Wandel der Zeit. 50 Jahre Zivil- und Bevoelkerungsschutz in Deutschland. Bonn: FOCPDA.

Geyer, M. 2001. Cold War Angst: The Case of West-German Opposition to Rearmament and Nuclear Weapons. In Miracle Years, ed. H. Schissler, 376-408. Princeton, NJ: Princeton University Press.

Grant.M. 2009. After the Bomb: Civil Defence and Nuclear War in Cold War Britain, 1945 1968, Basingstoke: Palgrave, 2009.

Goersch, H. \& Werner, U. (2011) Empirische Untersuchung der Realisierbarkeit von Massnahmen zur Erhoehung der Selbstschutzfaehigkeit der Bevoelkerung. Retrieved from http://www.bbk.bund.de/SubSites/SK/DE/Publikationen/Zivilschutzforschung/Forschungim-Bevoelkerungsschutz/DownloadsFiB/Band-15_Neu.pdf? blob=publicationFile

Hanshew, K. 2012. Terror and democracy in West Germany. Cambridge, New York: Cambridge University Press.

Hennessy, P. 2003. The Secret State: Whitehall and the Cold War. London: Penguin.

Japan Meteorological Agency. 2014a. The Great East Japan Earthquake - Portal Site. http://www.jma.go.jp/jma/menu/jishin-portal.html.

Japan Meteorological Agency. 2014b. About Tsunami. http://www.jma.go.jp/jma/kishou/know/faq/faq26.html. 
Klein, N, 2014. The Shock Doctrine: the rise of disaster capitalism. London: Penguin.

Krüger P. 2007. Geschlechterdifferenzierungen im ehrenamtlichen Engagement: Drei Organisationen im Vergleich. (Unpublished doctoral thesis) University of Tuebingen: Tuebingen, Germany.

Kuhn, J. 2005. Der Schutz der kritischer Infrastrukturen unter besonderer Beruecksichtigung von kritischen Informationsinfrastrukturen. Hamburg: Institute for Peace Research and Security Policy.

Liotta, P.H. 2002. Boomerang effect: the Convergence of National and Human Security. Security Dialogue 33(4): 473-488.

Lutterbeck, D. 2005. Blurring the Dividing Line: The Convergence of Internal and External Security in Western Europe. European Security 14(2): 231-253.

The Expert Committee to Discuss Disaster Education and Management Considering the Lessons Learnt From the Great East Japan Earthquake. 2012. Higashinihondaishinsai o uketa bosaikyoiku/bosaikanri to ni kansuru yushikishakaigi saishu hokoku [The Final Report of the Expert Committee to Discuss Disaster Education and Management Considering the Lessons Learnt From the Great East Japan Earthquake]. http://www.mext.go.jp/b_menu/shingi/chousa/sports/012/toushin/1324017.htm.

MEXT. 2011. Shochugakko gakushushidoyoryo no kaitei no pointo [The Key Points of the Revision of the Course of http://www.mext.go.jp/component/a_menu/education/micro_detail/_icsFiles/afieldfile/2 011/03/30/1234773_001.pdf.

Ministry of Civil Defence and Emergency Management. 2013. Civil Defence Emergency Management Framework in New Zealand. Presentation given at MCDEM, May 2014.

Ministry of the Interior. 2009. National Strategy for Critical Infrastructure Protection. Bonn: Ministry of the Interior.

MLIT. 2015. The role of MLIT. http://www.mlit.go.jp/about/index.html.

MLIT. 2002. Overview of Erosion Control Measures. Reference Materials for the First Meeting of the Erosion Control Measures Committee. www.mlit.go.jp/river/sabo/mudslide_cpa/ref1.pdf.

Morris, P., Rao, N. and Sayed, Y. 2014. Editorial: converging and diverging comparisons. Compare 44(5): 685-687.

National Police Agency. 2014. The Damage Statistics of the Great East Japan Earthquake and the Police Measures.

Skocpol, T. and Somers, M. 1980. The uses of comparative history in macrosocial inquiry. Comparative Studies in Society and History 22(2): 174-197. doi: http://dx.doi.org/10.1017/S0010417500009282

Taylor, M. and Moeed, A. 2013. Curriculum shockwaves? Geography, science and the Canterbury earthquakes. Curriculum Matters 9, 8-28.

Tsukui, S. 2012. Daisaigai to ho [Large-scale Disasters and Laws]. Tokyo: Iwanami Shoten. United Nations Secretariat of the International Strategy for Disaster Reduction (UN/ISDR). 2008. Disaster Preparedness for Effective Response: Guidance and Indicator Package for Implementing Priority Five of the Hyogo Framework. Geneva: UN/ISDR and the United Nations Office for Coordination of Humanitarian Affairs (UN/OCHA).

Würger, D. 2009. Wer nicht fragt, bekommt keine Antworten. Berlin auf der Suche nach Lösungen für ein Problem. In Bevoelkerungsschutz. Demographischer Wandel: Risiko oder Chance?, BBK. Bonn: FOCPDA. 
Table: Characterising the approaches to CIP and preparedness education

\begin{tabular}{|c|c|c|c|}
\hline \multirow{2}{*}{ Country } & \multirow{2}{*}{$\begin{array}{l}\text { Approach to } \\
\text { CIP }\end{array}$} & \multicolumn{2}{|c|}{ Preparedness education } \\
\hline & & Educational mode & Characteristics \\
\hline UK & $\begin{array}{l}\text { Critical is } \\
\text { secret }\end{array}$ & Information campaign & $\begin{array}{l}\text { Localised } \\
\text { Education is not orientated towards } \\
\text { preparedness education. } \\
\text { No pedagogical schemes for preparedness, } \\
\text { except distinct types of education in sites } \\
\text { of emergency. } \\
\text { (eg. information and guidance around } \\
\text { COMAH sites) }\end{array}$ \\
\hline US & $\begin{array}{l}\text { Everything is } \\
\text { critical }\end{array}$ & $\begin{array}{l}\text { Community resilience } \\
\text { LLL approach } \\
\text { Public pedagogy } \\
\text { Volunteering } \\
\text { Information campaign }\end{array}$ & $\begin{array}{l}\text { All-around } \\
\text { Pedagogical schemas for involving citizens } \\
\text { in preparedness. }\end{array}$ \\
\hline Germany & $\begin{array}{l}\text { Germany: CIP } \\
\text { as } \\
\text { uncoordinated } \\
\text { and } \\
\text { preparedness } \\
\text { as voluntary }\end{array}$ & Volunteering & $\begin{array}{l}\text { Uncoordinated and voluntary } \\
\text { Education is not orientated around } \\
\text { preparedness education. } \\
\text { There are distinct types of education } \\
\text { around emergency, targeting specific } \\
\text { groups of the population. } \\
\text { (e.g. volunteering privileging certain } \\
\text { categories of volunteer) }\end{array}$ \\
\hline Japan & $\begin{array}{l}\text { Critical is } \\
\text { usual }\end{array}$ & $\begin{array}{l}\text { School curriculum } \\
\text { Community resilience } \\
\text { LLL approach } \\
\text { Public pedagogy } \\
\text { Volunteering } \\
\text { Information campaign }\end{array}$ & $\begin{array}{l}\text { Co-ordinated and nationwide } \\
\text { Education has an orientation towards } \\
\text { preparedness education. } \\
\text { Pedagogical schemas for involving citizens } \\
\text { in preparedness. }\end{array}$ \\
\hline $\mathrm{NZ}$ & $\begin{array}{l}\text { Resilient New } \\
\text { Zealand }\end{array}$ & $\begin{array}{l}\text { Community resilience } \\
\text { approach } \\
\text { LLL approach } \\
\text { Public pedagogy } \\
\text { Volunteering } \\
\text { Information campaign }\end{array}$ & $\begin{array}{l}\text { Co-ordinated and integrated } \\
\text { Preparedness education not included in } \\
\text { national curriculum. } \\
\text { However, widespread pedagogical } \\
\text { schemes for involving citizens in } \\
\text { preparedness as part of public information } \\
\text { campaigns and community resilience. }\end{array}$ \\
\hline
\end{tabular}

